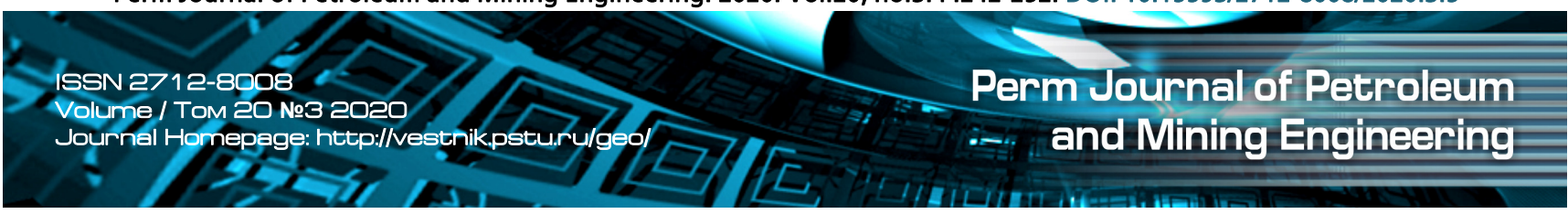

UDC 622.276 .6

Article / Статья

(C) PNRPU / ПНИПУ, 2020

\title{
Evaluation of Waterflooding Effectiveness in the Tournaisian- Famennian Deposit of the Magovskoye Field
}

\section{Nadezhda A. Lyadova, Vladimir A. Demchenko}

PermNIPIneft branch of LUKOIL-Engineering LLC in Perm (3a Permskaya st., Perm, 614066, Russian Federation)

\section{Оценка эффективности системы заводнения турнейско-фраменской залежи Маговского месторождения}

\section{Н.А. Лядова, В.А. Демченко}

Филиал ООО «ЛУкОЙЛ-Инжиниринг» «ПермНИПИнефть» в г. Перми (Россия, 614990, г. Пермь, ул. Пермская, 3а)

\section{Received / Получена: 03.02.2020. Принята / Accepted: 15.06.2020. Published / Опубликована: 17.08.2020}

Keywords:

waterflooding, enhanced oil recovery, well intervention, carbonate reservoir, reserves, deposit, field, development, well, asset value.

Ключевые слова: система заводнения, интенсификация добычи нефти, геолого-технические мероприятия, карбонатный соллектор, запасы, залежь, месторождение, разработка, скважина, ценность актива.
Waterflooding effectiveness of the structurally complex carbonate reservoir in the Tournaisian-Famennian formation of the Magovskoye field is studied. This formation is characterised with hardened geological conditions, which affects the development efficiency. The work includes analysis of the history and current state of the formation development, production and injection well performance, the reservoir natural energy contents, the reservoir pressure performance across wells, formation geology and lithofacies structure. A correlation was established between the well performance and lithofacies heterogeneity of the formation.

A combination of boundary and marginal flooding systems is arranged at the formation target, which shows low efficiency. The wells located in the edge reservoir areas exhibit low reservoir pressures; these areas feature low reservoir properties. Concurrently, there is a difference between the upper and lower parts of the section. The wells drilled into the lower part of the section show a positive water production performance and positive energy level, which is associated with the aquifer influence. The wells drilled into the upper part of the section show lower reservoir properties, higher compartmentalisation and no aquifer influence. The wells located in the areas with low reservoir pressures were reviewed, the reasons for the depleted content of energy were identified and research proposals were provided. Furthermore, we considered the well intervention operations performed at the formation in question and at formations of similar fields in the corresponding geological field conditions, and identified operations with the highest technological effects.

As a result of the studies, well intervention operations were proposed, subject to the specific structure of the lithofacies zones and the nature of the relationship between production and injection wells. It will result in enhancing the waterflood system effectiveness and affecting the target development efficiency, in general.

Исследуется эффективность системы заводнения в сложнопостроенном карбонатном коллекторе турнейскофаменского объекта Маговского месторождения. Данный объект характеризуется сложными геологическими условиями, что напрямую отражается на эффективности его разработки. В ходе работы проанализированы: история и текущее состояние разработки объекта, динамика работы добывающих и нагнетательных скважин, энергетическое состояние объекта, динамика пластового давления по скважинам, геологические особенности пласта и литологофациальное строение. Установлена связь между работой скважин и литофациальной неоднородностью пласта.

На объекте организована внутриконтурная в сочетании с приконтурной система заводнения, которая характеризуется низкой эффективностью. По ряду скважин, расположенных в краевых частях, отмечается пониженное пластовое давление, данные участки характеризуются ухудшенными фильтрационно-емкостными свойствами. Также выделяют различие между верхней и нижней частью разреза: скважины, вскрывшие нижнюю часть разреза, характеризуются положительной динамикой добычи жидкости и положительным энергетическим состоянием, что в свою очередь связано с влиянием законтурной области; скважины, вскрывшие верхнюю часть разреза, характеризуются худшими фильтрационно-емкостными свойствами, более высокой расчлененностью и отсутствием влияния законтурной области. Проанализированы скважины, расположенные в зонах с пониженным пластовым давлением, выявлены причины низкого энергетического состояния, даны предложения по проведению исследований. Также рассмотрены геолого-технические мероприятия, проводимые на рассматриваемом объекте и на объектах месторождений-аналогов в соответствующих геолого-промысловых условиях, определены мероприятия с наибольшим технологическим эффектом.

В результате исследований предложены геолого-технические мероприятия с учетом особенностей строения литолого-фациальных зон, характером взаимосвязи добывающих и нагнетательных скважин, которые повысят эффективность системы заводнения и в целом положительно отразятся на эффективности разработки объекта.

Nadezhda A. Lyadova (Author ID in Scopus: 36712086700) - PhD in Geological and Mineralogical Sciences, Associate Professor, Deputy General Director - Branch Director (tel.: +007 34223367 81, e-mail: nadezhda.lyadova@pnn.lukoil.com).

Vladimir A. Demchenko - $1^{\text {st }}$ category Engineer (tel.: +7 91298089 20, e-mail: Vladimir.Demchenko@pnn.lukoil.com). The contact person for correspondence.

Лядова Надежда Алексеевна - кандидат геолого-минералогических наук, доцент, заместитель генерального директора - директор филиала, (тел.: +007 3422336781 , e-mail: nadezhda.lyadova@pnn.lukoil.com).

Демченко Владимир Александрович - инженер I категории (тел.: + 7912980 89 20, e-mail: Vladimir.Demchenko@pnn.lukoil.com). Контактное лицо для переписки. 


\section{Introduction}

Currently, the development of carbonate deposits entails a range of complicating factors due to their complex geology. The existing development systems do not ensure effectiveness and need an upgrade, findings and application of advanced oil recovery technologies. The case of the Tournaisian-Famennian deposits of the Yuzhno-Rayevsky dome of the Magovskoye field demonstrates that despite the arranged waterflood system, and supplementary injection points, as well as the high cumulative voidage replacement ratio, there are areas with a very poor content of energy, which results in a decreased well productivity and oil production potential. In this regard, a crucial task is to evaluate the waterflood system effectiveness and elaborate a set of recommendations on stimulating reservoir energy contents and uniform areal recovery of reserves.

This work is intended at identifying the reasons behind the low waterflooding effectiveness and reservoir low content of natural energy, and at elaborating a set of recommendations on its enhancement.

\section{Waterflooding Effectiveness Evaluation}

The Magovskoye oil and gas condensate field has eight development targets. Over $40 \%$ of recoverable reserves are concentrated in the Tournaisian-Famennian formation target of the Yuzhno-Rayevsky dome. The formation is in the third stage of development, the withdrawal level of initial recoverable reserves is less than $25 \%$.

The commercial development of the formation under study was started in 1999 with bringing in well No. 15 with a daily oil flow rate of 40 tons. In 2003, wells No. 16 and No. 13 were put into production with daily oil flow rates of 18.1 and 34 tons, respectively. Prior to 2009, the deposit was exploited with three wells placed in different parts of the area. Well No. 15 exhibits a decline in reservoir pressure and water production, as to wells No. 13 and No. 16, no reservoir pressure readings were taken when brought in (Fig. 1, a).

From 2006 to 2007, there was a surge in watercut from $4.4 \%$ to $26.4 \%$, associated with a formation water breakthrough into the lower perforation intervals of wells No. 13 and No. 16; the isolation squeeze reduced the watercut to $15.3 \%$ (Fig. 1, b).

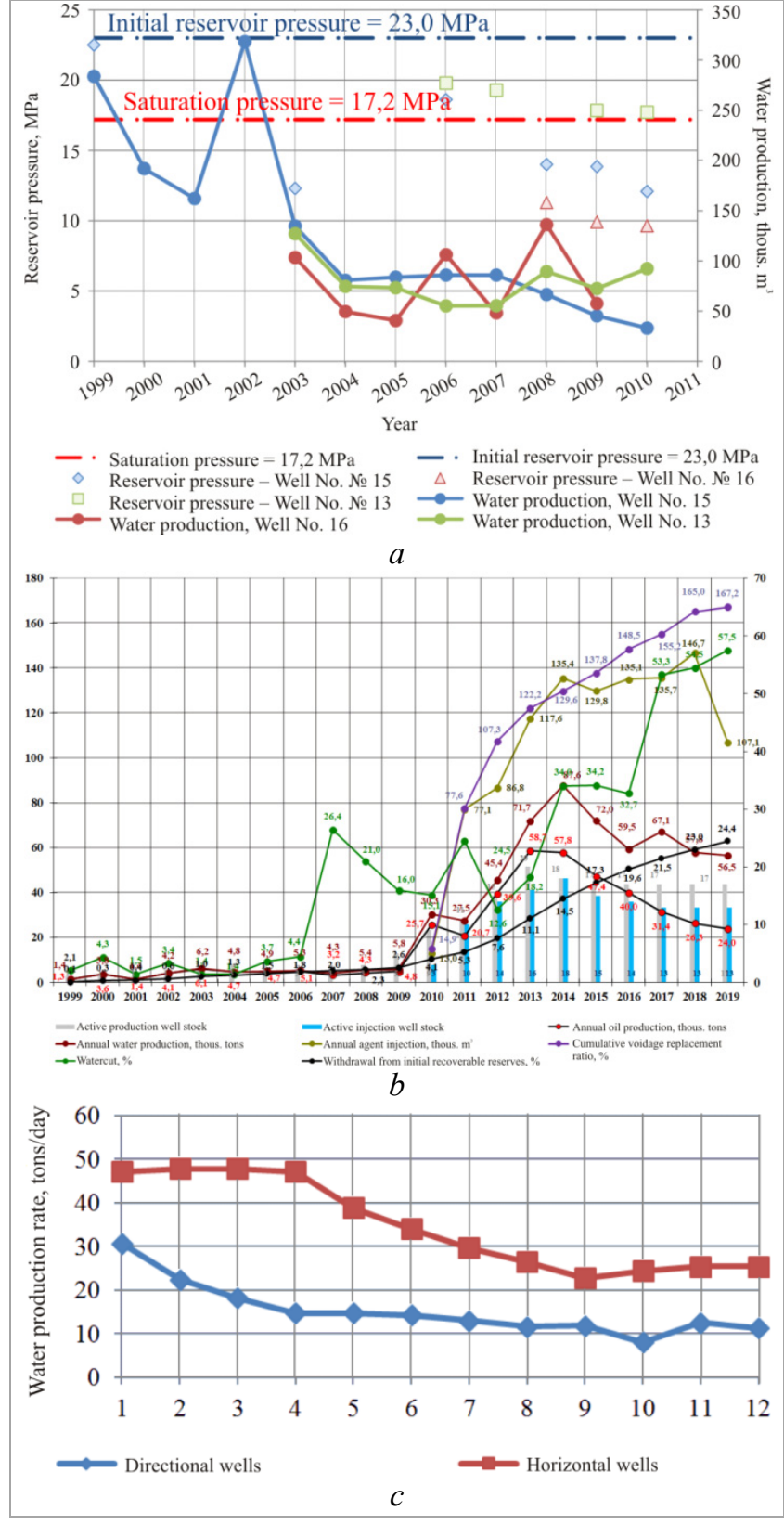

Fig. 1. Formation target $\mathrm{C}_{1} \mathrm{t}-\mathrm{D}_{3} \mathrm{fm}$, Yuzhno-Rayevsky uplift: $a$ is reservoir pressure and water production performance by wells nos. 13, 15 and 16; $b$ is the Magovskoye field development schedule; $c$ is the water production performance in the first year of horizontal and directional wells operation

From 2009 to 2015, the formation was drilled using a five-point pattern layout $(500 \times 500 \mathrm{~m})$, with a well spacing of 18 ha. As of the current date, artificial lifting is used for oil recovery.

The waterflood system was formed almost simultaneously with bringing-in the production wells. In 2010, three producer wells were converted to injectors, and in 2011, seven 
injection wells from the development drilling were put into production. The applied waterflood system is a combination of boundary and marginal flooding systems. Despite the concurrent bringing-in of production and injection wells, the water production levels dropped by one-third over a relatively short period of time of 3 years (see Fig. 1, b). The current oil recovery factor (ORF) for the entire $\mathrm{C}_{1} \mathrm{t}-\mathrm{D}_{3}$ fm formation of the Yuzhno-Rayevsky dome of the Magovskoye field reached $6.5 \%$ [1].

The wells were brought in with high water production rates followed by a sharp downward trend in productivity, which eventually resulted in a failure to meet the design oil production rates and led to the elaboration of an addendum to the reservoir management plan for the Magovskoye oil and gas condensate field in 2017 (Fig. 1, c). It follows from the obtained data that the directional wells show the highest decline rate. During the first 12 months of operation, the water production rate dropped on average by $60 \%$ for the directional wells and by $47 \%$ for the horizontal wells. This fact indirectly indicates depleted energy contents in the deposit areas with the highest water withdrawals $[2,3]$.

Difficult geological conditions of the development is the primary reason of the dramatic drop in water production rates, i.e. low flow properties (permeability of $0.004 \mathrm{mD}$ ), high compartmentalisation (41.4 units) and the presence of vertical fractures [4-8].

The decline in well production rates occurred with various intensities depending on a well location in the area. There are four facies zones in the area of the Tournaisian-Famennian reef mass: bioherm core, upper part of the back apron, lower part of the back apron and reef crest (Fig. 2) [9-19].

The maximum productivity loss from the initial level was in the reef slope facies zone (85\%). The loss of productivity in the lower part of the back apron was $80 \%$; the most stable in operation are the wells of the upper part of the back apron and the bioherm core, with productivity loss rates of $46 \%$ and $53 \%$, respectively. Figure 3, a, shows a correlation of the average daily oil flow performance across the facies zones, where a value of specific yield per meter of productive thickness entered by perforation, was used.

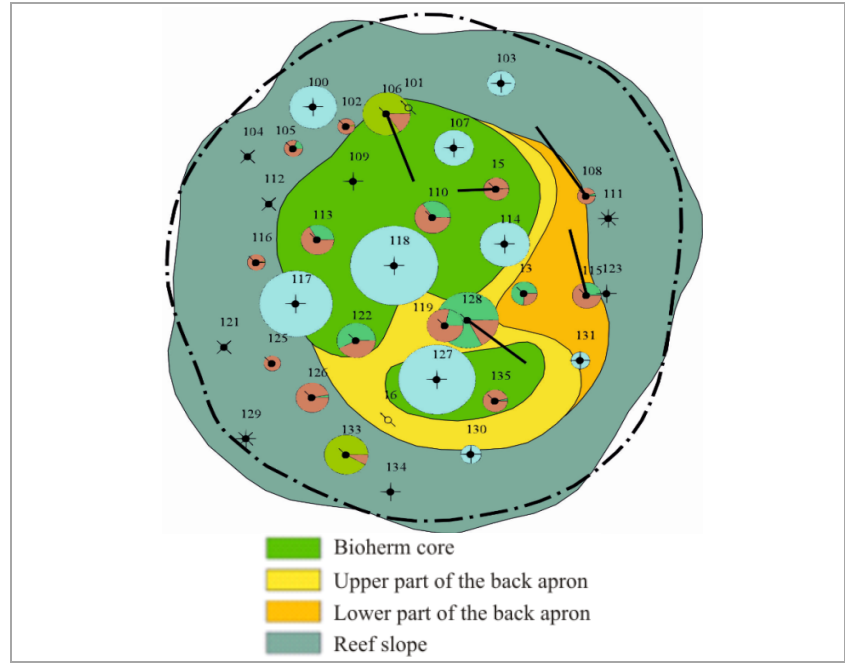

Fig. 2. Map of the current operation of the TournaisianFamennian formation target with facies zones

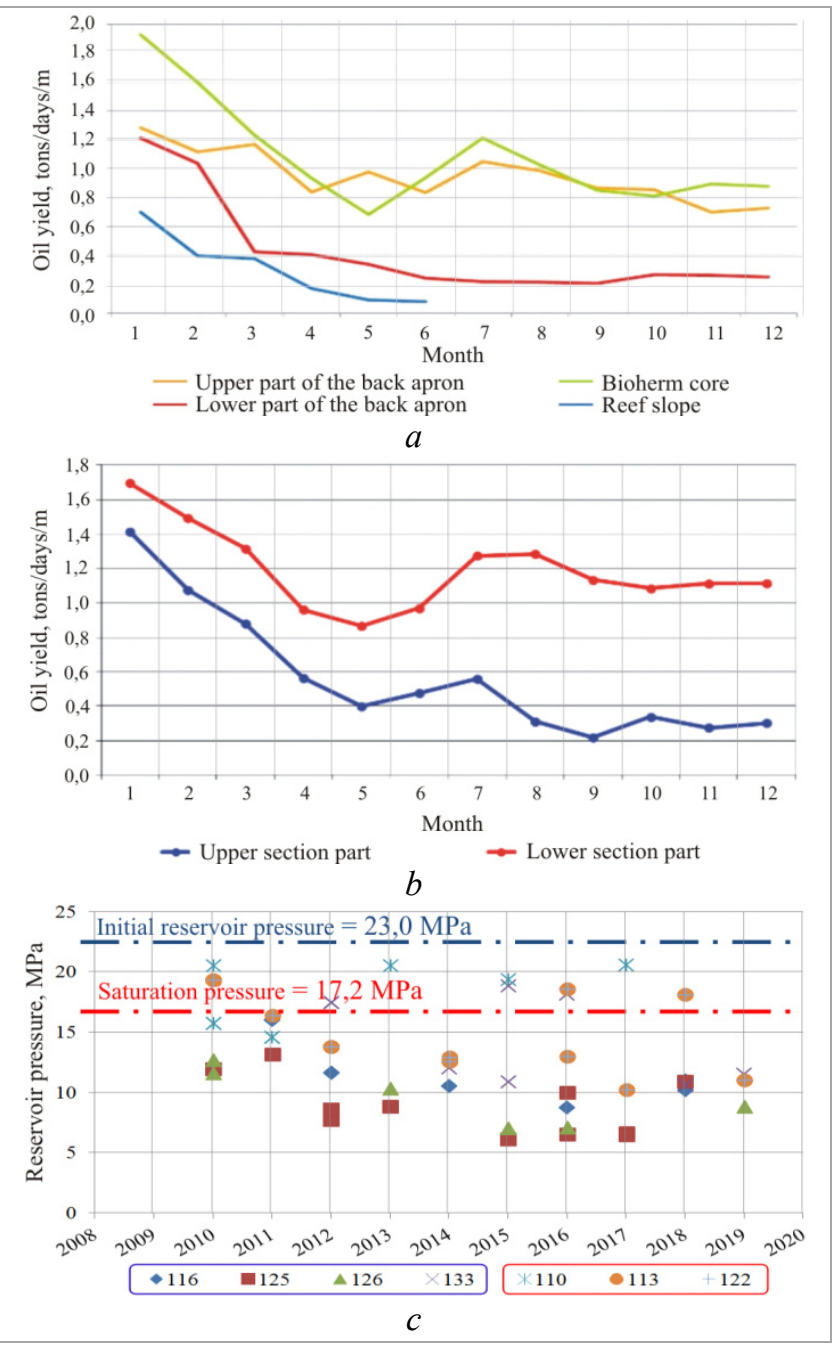

Fig. 3. Trends: $a$ is oil production performance in the first year of wells operation by facies zones; $b$ is oil yield performance in the first year of wells operation by formations $\mathrm{D}_{3} \mathrm{fm}$ and $\mathrm{D}_{3} \mathrm{fr} ; c$ is reservoir pressure performance by wells that entered the upper and lower section parts 
Following the comprehensive analysis data, we also determined differences between the upper and lower parts of the reef reservoir. The lower part of the reservoir is most productive, with an average permeability value of $6.75 \mathrm{mD}$ for the porous reservoir, and $4.73 \mathrm{mD}$ for the fractured reservoir. The upper part of the reef reservoir shows lower reservoir properties, higher compartmentalisation and no aquifer influence, with an average permeability value of $0.79 \mathrm{mD}$ for the porous reservoir, and $2.02 \mathrm{mD}$ for the fractured reservoir.

Figure $3, b$, plots a trend in oil yield performance for the lower and upper parts of the reef reservoir. The reservoir pressure in the deposits of the lower part of the section is higher than that in the upper part of the section, which signifies high heterogeneity of flow properties of the organogenic mass; Figure $3, c$, shows the reservoir pressure readings. The over-pressure in the lower part of the section was surveyed before the injection wells were brought in, which indicates the aquifer's strength [20].

Thus, the above factors control the low oil withdrawal rates, the uneven recovery of oil reserves, reduced well productivity and low energy contents.

The average daily well production rate is 4.8 tons for oil and 11.6 tons for water. For most of wells, the daily oil flow rate is below 5 tons, while for the half of them, the daily flow rate is below 1 ton. The low flow rates are due to low reservoir properties, depleted energy content and high producing watercut. More than one third of the well stock $(41.2 \%)$ feature less than $10 \%$ watercut, while a high watercut (over $60 \%$ ) is typical of four wells. The wells located in the lowpressure areas show low mean daily flow rates and low withdrawal oil reserves.

The charts of the current and cumulative withdrawals, pressure and recovery of reserves were analysed to evaluate the effectiveness of the waterflood system.

The arrangement of the injection process contributed to stabilisation and increase of the energy content for a number of production wells located near the injection points. Most of the injection volume $(74 \%)$ is performed in the central part of the deposit into the Fr reservoir (wells nos. 109, 118, 127, 117 and 114). Despite the positive impact of the waterflood system, the wells located in the edge reservoir areas of the deposit show critically low pressure values.

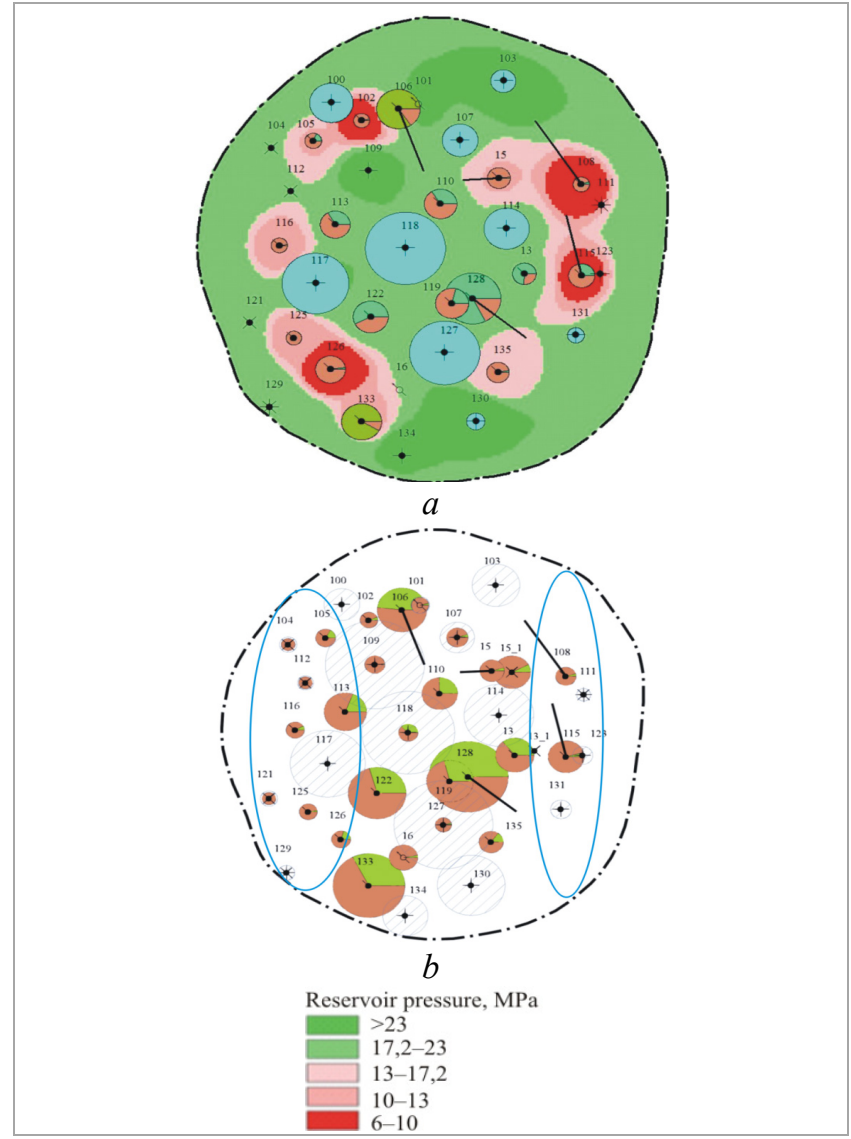

Fig. 4. Formation target $\mathrm{C}_{1} \mathrm{t}-\mathrm{D}_{3} \mathrm{fm}$ of the YuzhnoRayevsky uplift: $a$ is the layout of current energy content; $\mathrm{b}$ is the chart of cumulative withdrawal

Pressure buildup above the bubble point (saturation) pressure is observed in the wells located in the central part of the deposit. Pressure decline in the wells located in the edge reservoir areas, in generally, has a negative impact on the overall indicator performance.

Areas with the abnormally high reservoir pressure (above the initial reservoir pressure) are identified in the area of injection wells in the central part of the formation target (Fig. 4, a). In general, the energy content of the deposit in question is poor; the current reservoir pressure (17.75 MPa) exceeds the bubble-point (saturation) pressure $(16.2 \mathrm{MPa})$, yet there are areas with the pressure below the bubble-point.

It should be taken into account that low reservoir pressure in a number of wells occurs against the annual voidage replacement of $202 \%$; the volume of the injected water exceeds by far the water withdrawals. The current water breakthrough rates are low, indicating that the injected water partially discharges into the aquifer.

Most of the reservoir area is water-swept. The recovery of the reserves through the section is 
non-uniform. Figure $4, \quad b$ shows a chart of cumulative withdrawals, clearly indicating that the wells located in the edge areas have a low level of the reserve recovery. High and low withdrawal areas are defined across the deposit, showing varying waterflooding effectiveness. The high oil withdrawal areas are mostly covered by the injection wells and are associated with the lower part of the deposit section. Low waterflooding effectiveness is observed in the upper part of the section and in the edge areas. The upper part of the formation with low permeability intervals remains unswept by drainage. The wells located in these areas show a low level of oil withdrawal [21-35].

The analysis identified the areas of low reservoir pressure and reserve recovery. Let us consider the wells located in these areas: injection point of well No. 114 and horizontal well No. 108GS (Fig. 5, a).

Well No. 108GS has a low downhole pressure of 7.7 $\mathrm{MPa}$, resulting from no influence of injection well No. 114 due to a mismatch between oil withdrawal and water injection intervals. In 2019, re-perforation and additional perforation of the upper part of the formation was performed in well No. 108GS, the daily rate having increased by 9.9 tons (however, there was a sharp drop in oil production: the flow rate decreased by $29 \%$ over five months). The section also shows production well No. 128GS and injection well No. 127, the withdrawal and injection intervals are matching, the production well reservoir pressure is above the bubble-point pressure (17.7 MPa). The surrounding wells No. 13_2 and No. 15 entered the upper part of the section, while well No. 114 did not enter the upper part of the section (Fig. 5, b).

All production wells near the injection point of well No. 114 entered the upper part of the section. The following well intervention operations are proposed: additional perforation of the upper part of the section in the injection well No. 114, flow rate measurement and matching the intervals of the withdrawal and injection of water for wells No. 114 and No. 108GS [36].

Let us consider injection wells No. 109 and No. 118: the situation with the injection distribution through the section is similar, the lower part of the section is active, while water discharge into the water-saturated area is observed (Fig. 5, $c, d$ ).

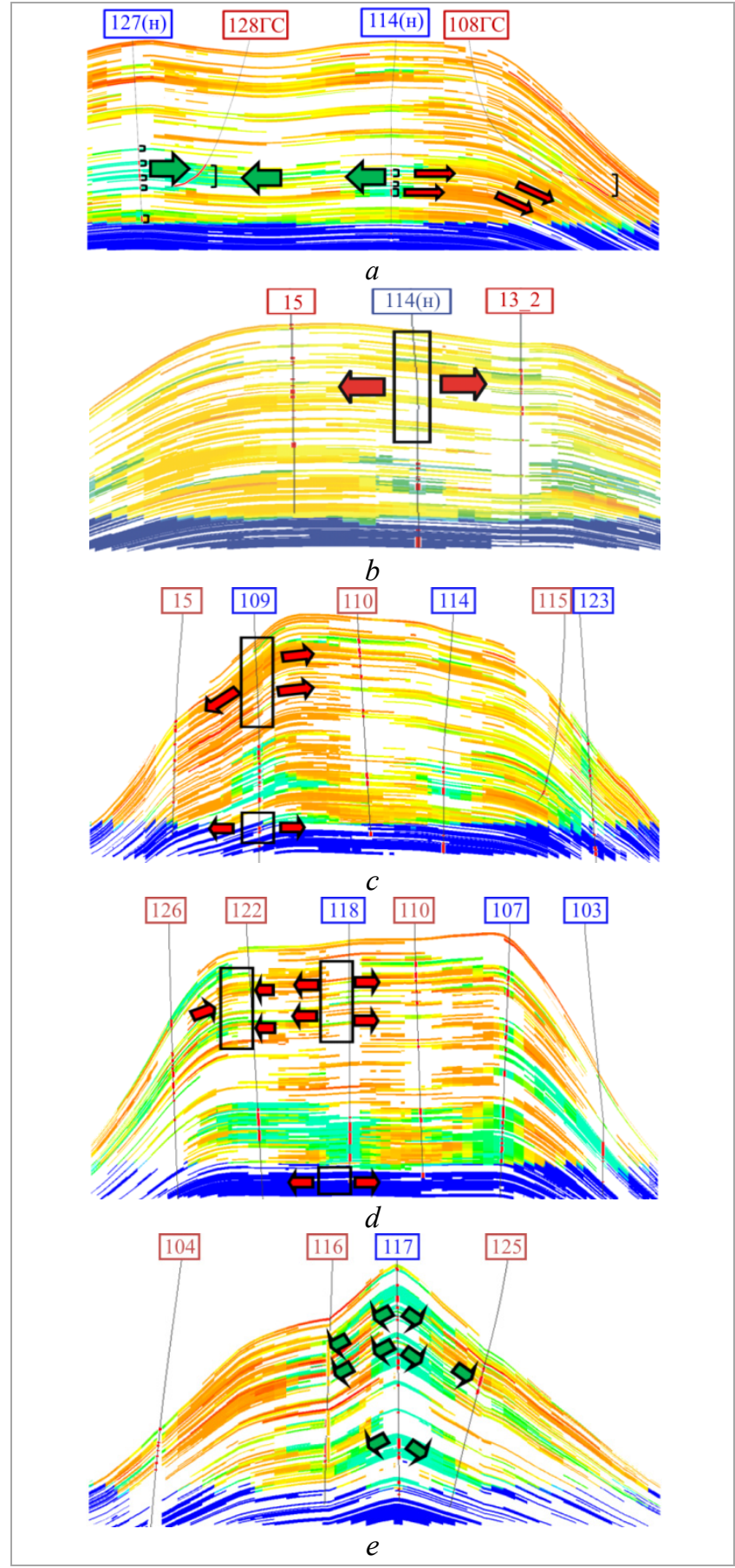

Fig. 5. Well profile as illustrated by oil saturation cube: $a$ - well No. 127-128GS-114-108GS; $b$ - well No. 15-114-13_2; $c$ - well No. 115-114-110-109-105; $d$ - well No. 107-110-

118-122-126; $e$ - well No. 104-116-117-125

Production well No. 122 did not enter the upper part of the section by perforation, and the reserves were recovered nonuniformly through the section (see Fig. 4, a).

A similar situation is observed in injection well No. 131: there is no influence on production well No. 115, and the upper part of the section was not entered. Well intervention 
operations are proposed including additional perforation of the upper part of the section in production and injection wells, as well as the isolation squeeze of the perforation intervals in injection wells where water is discharged into the water-saturated area.

Injection well No. 123 produces in two formation targets $\mathrm{C}_{2} \mathrm{~b}-\mathrm{C}_{1} \mathrm{~s}$ and $\mathrm{C}_{1} \mathrm{t}-\mathrm{D}_{3} \mathrm{fm}$. It is located in a close proximity to production well No. 115 , yet has no influence on the production well due to its low injectivity $\left(10 \mathrm{~m}^{3} /\right.$ day $)$. Since the near-bottomhole location of well No. 115, there is a risk of the injected water breakthrough and producing watercut. Perforation interval isolation squeeze is proposed at formation $\mathrm{C}_{1} \mathrm{t}-\mathrm{D}_{3} \mathrm{fm}$.

Injection well No. 130 produces with an injectivity of up to $5 \mathrm{~m}^{3} /$ day and has no influence on production well No. 135. Injection is inefficient under conditions of lowpermeability, highly compartmentalised reservoir with low injectivity. The applicable design engineering documentation provides for the drilling of horizontal wells for oil production in 2021 as well as from the production and injection wells nos. 116, 118, 126 and 130.

As a positive example, the injection point of well No. 117 can be held up: the upper and lower parts of the section were entered by perforation; as a result, wells No. 116 and No. 125 show positive performance in reservoir pressure (Fig. 5, e). In 2019, enhanced oil recovery (EOR) procedures were performed in the wells (acid hydraulic fracturing with a propping agent), which resulted in the daily rate increase by 4.0 and 8.6 tons, respectively (however, well No. 116 showed a decline in oil production: the flow rate decreased by $84 \%$ over eight months). Well No. 126 showed a low reservoir pressure of $8.8 \mathrm{MPa}$, and no influence is probably due to the well spacing.

The low waterflooding effectiveness results from the non-uniform recovery of reserves associated with permeability heterogeneity and high compartmentalisation of the reef reservoir. Not all drilled wells entered the entire productive thickness; there is a mismatch between the intervals of injection and withdrawal of water, which also leads to uneven recovery of reserves. Bottomwater may also contribute to the watercut.

The proposed well intervention operations including the additional perforation of intervals untapped through the section without the use of oil recovery enhancement and stimulation methods will be ineffective. The formation features low permeability, a high degree of compartmentalisation and heterogeneity across the area and through the section, which has a significant impact on the well productivity and intervention effectiveness [37-39].

As a rationale for the application of the oil recovery enhancement and stimulation methods, the effectiveness of the corresponding technologies thereof applied at formation target $\mathrm{C}_{1} \mathrm{t}-\mathrm{D}_{3} \mathrm{fm}$ of the Yuzhno-Rayevsky uplift of the Magovskoye field was reviewed.

A total of 48 well intervention operations were performed at formation target $\mathrm{C}_{1} \mathrm{t}-\mathrm{D}_{3} \mathrm{fm}$ of the Yuzhno-Rayevsky uplift of the Magovskoye field over a period from 2010 to 2020. The Table shows the outcome of the well intervention operations performed in the production and injection wells.

A large number of well intervention operations are currently being performed at the fields in Perm Krai, proppant hydraulic fracturing technologies are most commonly applied. In 2019, two operations were performed at the formation in question; this technology brings a positive technological effect that amounted to 6.3 tons per day. The high-rate acid hydraulic fracturing technology was also tried at the comparable formation target, and two operations with an effect of 10.2 tons per day were performed. Thus, high-rate acid hydraulic fracturing is recommended to enhance withdrawal at formation target $\mathrm{C}_{1} \mathrm{t}-\mathrm{D}_{3} \mathrm{fm}$ of the YuzhnoRayevsky uplift, if the wells meet the technology applicability criteria.

Twenty-six well intervention operations were performed in the injection wells. Most of the operations were aimed at increasing injectivity through the use of acid hydraulic fracturing technology and arranging new injection points.

During the development of wells for injection, as well as for the injectivity recovery, acid treatments, acid hydraulic fracturing and proppant hydraulic fracturing were also performed. To stimulate injectivity of the injection wells, further testing of the high-rate acid hydraulic fracturing technology is recommended [40-43].

As of the date of the review, drilling of the planned well stock was completed. There was a rapid decline in productivity in the production wells during the initial period of operation 
Well intervention outcome at formation target $\mathrm{C}_{1} \mathrm{t}-\mathrm{D}_{3} \mathrm{fm}$ of the Yuzhno-Rayevsky uplift

\begin{tabular}{|c|c|c|c|c|c|c|c|c|}
\hline $\begin{array}{l}\text { Well } \\
\text { stock }\end{array}$ & Technology & $\begin{array}{c}\text { Amount } \\
\text { of well } \\
\text { intervention } \\
\text { jobs }\end{array}$ & $\begin{array}{l}\text { Oil } \\
\text { production } \\
\text { gain, tons }\end{array}$ & $\begin{array}{l}\text { Specific oil } \\
\text { production } \\
\text { gain, tons }\end{array}$ & $\begin{array}{l}\text { Mean effect } \\
\text { time, days }\end{array}$ & $\begin{array}{l}\text { Average } \\
\text { initial gain, } \\
\text { tons/day }\end{array}$ & $\begin{array}{c}\text { Average } \\
\text { daily gain } \\
\text { throughout } \\
\text { effect time, } \\
\text { tons/day }\end{array}$ & $\begin{array}{l}\text { Operations } \\
\text { period, year }\end{array}$ \\
\hline \multirow{10}{*}{$\begin{array}{l}0 \\
\overline{0} \\
3 \\
\overline{0}\end{array}$} & Sidetrack drilling & 2 & $17,676.7$ & $8,838.4$ & 2,454 & 8.3 & 5.9 & $2003-2015$ \\
\hline & Viscoelastic compositions & 1 & $2,547.5$ & 2547.5 & 636 & 21.9 & 4.0 & 2012 \\
\hline & Additional penetration & 4 & $3,819.9$ & 3819.9 & 362 & 9.5 & 8.3 & $2013-2018$ \\
\hline & Re-penetration & 2 & $5,432.7$ & $5,432.7$ & 735 & 9.3 & 3.7 & 2017 \\
\hline & Hydrochloric acid treatment & 3 & $3,650.6$ & $3,650.6$ & 722 & 3.9 & 2.3 & $2017-2019$ \\
\hline & Acid hydraulic fracturing & 5 & $2,303.1$ & 460.6 & 133 & 7.1 & 3.4 & 2013 \\
\hline & $\begin{array}{l}\text { Acid hydraulic fracturing } \\
\text { with a proppant }\end{array}$ & 2 & 637.9 & 637.9 & 148 & 7.6 & 6.3 & 2019 \\
\hline & $\begin{array}{l}\text { Acid hydraulic fracturing } \\
\text { with a diverting agent }\end{array}$ & 1 & 381.8 & 381.8 & 55 & 11.4 & 6.9 & 2012 \\
\hline & Radial drilling & 1 & $1,920.9$ & $1,920.9$ & 473 & 10.0 & 4.1 & 2006 \\
\hline & Remedial isolation cementing & 1 & 151.5 & 151.5 & 74 & 9.1 & 2.9 & 2008 \\
\hline & Total for oil wells & 22 & $25,143.7$ & - & & 8.4 & - & - \\
\hline \multirow{9}{*}{ 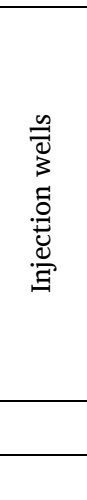 } & $\begin{array}{l}\text { Bringing a new injection } \\
\text { well into production }\end{array}$ & 3 & 180.3 & - & 63.0 & - & - & 2010-2012 \\
\hline & Acid hydraulic fracturing & 2 & 403.3 & - & 30.5 & - & - & $2012-2013$ \\
\hline & $\begin{array}{l}\text { Acid hydraulic fracturing with } \\
\text { proppant settling }\end{array}$ & 2 & 282.2 & - & 80.0 & - & - & 2016 \\
\hline & $\begin{array}{l}\text { Bringing a new injection well } \\
\text { into production with acid } \\
\text { hydraulic fracturing }\end{array}$ & 15 & $1,817.8$ & - & 58.5 & - & - & 2010-2014 \\
\hline & Additional penetration & 1 & 96.8 & - & 61 & - & - & 2018 \\
\hline & Re-penetration & 1 & $1,767.9$ & - & 67.5 & - & - & 2016-2018 \\
\hline & $\begin{array}{l}\text { Application of 'KSPEO' acidic } \\
\text { compound }\end{array}$ & 2 & 455.6 & - & 61 & - & - & 2018 \\
\hline & Total for injection wells & 26 & $3,916.6$ & - & - & - & - & - \\
\hline & Total & 48 & $29,060.3$ & - & - & 8.4 & - & - \\
\hline
\end{tabular}

associated with the hindered pressure connectivity to the drainage area under the conditions of poor flow properties and high compartmentalisation. Poor influence of the waterflood system due to limited or no pressure connectivity is observed. The existing development system requires implementation of the following measures:

- introduction of additional drainage zones with the maximum use of the drilled well stock (sidetracking) [44, 45]

- restoration of the operating well productivity

- perforation of intervals with the identified mismatch between the withdrawal and injection intervals

- isolation of intervals where injection is performed into water-saturated intervals

- pilot operations with the use or selection of new oil stimulation technologies in the lowproductivity, highly compartmentalised reservoir (with a long-term effect).

The following recommendations were provided to enhance the development and the waterflood system at the Tournaisian-Famennian formation target of the Yuzhno-Rayevsky uplift:
- for wells nos. 114, 131, 109, 118 and 122, it is recommended to perform an additional perforation of the upper part of the section, followed by the high-rate acid hydraulic fracturing. To reduce inefficient injection and increase the energy efficiency, it is recommended to isolate the bottom perforation intervals in wells nos. 109, 118 and 123 and to limit the injectivity in wells No. 109 and No. 118;

- for well No. 130, for the purpose of introducing additional drainage zones, it is recommended to drill horizontal wells for oil production in accordance with the applicable design engineering documentation.

The proposed measures will also lead to a positive reservoir pressure performance trend, uniform recovery of reserves, homogenisation of injectivity profile and improved oil mobility.

\section{Conclusions}

The analysis of the deposit development by natural drive has shown that the displacement intensity is significantly higher with the use of the waterflood system. When the deposit is developed by natural drive, there is a decrease in 
reservoir pressure, which entails a decrease in well productivity.

The waterflood system arrangement in the first stages allowed to significantly intensify the recovery of reserves. Additional injection points had a positive effect on pressure recovery in certain areas of wells.

Based on the lithofacies analysis results, a correlation was established between the well performance and lithofacies heterogeneity of the formation. Measures were proposed subject to the specific structure of the lithofacies zones, the nature of the relationship between production and injection wells, and the proven effectiveness of the recommended technologies in similar geological field conditions. The proposed measures will enhance the waterflood system effectiveness at the horizontal flow through the section and contribute to an increase in the oil recovery factor, which will increase the asset value.

\section{References}

1. Iushkov I.R., Khizhniak G.P., Iliushin P.Iu. Razrabotka i ekspluatatsiia neftianykh i gazovykh mestorozhdenii [Development and operation of oil and gas fields]. Perm': Permskii natsional'nyi issledovatel'skii politekhnicheskii universitet, 2013, $177 \mathrm{p}$.

2. Raspopov A.V., Kazantsev A.S., Antonov D.V. Vliianie monitoringa razrabotki na povyshenie effektivnosti ekspluatatsii neftianykh mestorozhdenii Permskogo kraia [The influence of development monitoring on oilfield exploration effectivness on the Perm territory]. Neftianoe khoziaistvo, 2012, no. 6, pp. 58-61.

3. Voevodkin V.L., Chertenkov M.V. Novye tekhnologii v kompanii «LUKOIL»: ot prostogo $\mathrm{k}$ slozhnomu [New technologies in LUKOIL: from simple to complicated]. Neftianoe khoziaistvo, 2019, no. 8, pp. 62-66. DOI: 10.24887/0028-2448-2019-8-62-66

4. Zaitsev R.A., Martiushev D.A. Ekspluatatsiia skvazhin s gorizontal'nym okonchaniem $\mathrm{v}$ razlichnykh geologo-fizicheskikh usloviiakh (na primere mestorozhdenii Permskogo kraia) [Operating experience with a horizontal wells in various geological and physical conditions (for example Perm edge fields)]. Burenie i neft', 2019, no. 5, pp. 42-46.

5. Martiushev D.A. Podkhod k opredeleniiu proizvoditel'nosti skvazhin $\mathrm{v}$ treshchinno-porovykh kollektorakh Verkhnego Prikam'ia [The lead up to determining the productivity of wells fractured porous type reservoirs of the Upper Kama region]. Burenie i neft', 2015, no. 2, pp. 44-46.

6. Martiushev D.A., Iliushin P.Iu. Ekspress-otsenka vzaimodeistviia mezhdu dobyvaiushchimi i nagnetatel'nymi skvazhinami na turne-famenskoi zalezhi Ozernogo mestorozhdeniia [Express assessment of the interaction between the production and injection wells in the Tournaisian-Famennian deposits of Ozernoe field]. Vestnik Permskogo natsional'nogo issledovatel'skogo politekhnicheskogo universiteta. Geologiia. Neftegazovoe i gornoe delo, 2016, vol. 15, no. 18, pp. 33-41. DOI: $10.15593 / 2224-9923 / 2016.18 .4$

7. Martiushev D.A., Mordvinov V.A. Izmenenie debita skvazhin neftegazokondensatnogo mestorozhdeniia pri snizhenii plastovykh i zaboinykh davlenii [Productivity of wells at oil and gas field while reducing the bottomhole and formation pressure]. Neftianoe khoziaistvo, 2014, no. 1, pp. 67-69.
8. Mordvinov V.A., Martiushev D.A., Chernykh I.A., Puzikov V.I. Otsenka parametrov plasta i produktivnosti skvazhin pri ego razrabotke na estestvennom rezhime [Evaluation of formation characteristics and wells productivity under primary oil recovery]. Neftianoe khoziaistvo, 2014, no. 6, pp. 31-33.

9. Putilov I.S. Primenenie veroiatnostno-statisticheskogo analiza dlia izucheniia fatsial'noi zonal'nosti turneifamenskogo karbonatnogo kompleksa Solikamskoi depressii [Application of probabilistic-statistical analysis to study the facies zoning of the Tournaisian-Famennian carbonate complex of the Solikamskaya depression]. Geologiia, geofizika $i$ razrabotka neftianykh i gazovykh mestorozhdenii, 2007, no. 10, pp. 16-19.

10. Putilov I.S., Vinokurova E.E., Boiarshinova M.G. Primenenie metodiki izucheniia litologo-fatsial'nogo stroeniia rifovykh rezervuarov na primere Pushkinskogo mestorozhdeniia [Application of the methodology for studying the lithologicalfacies structure of reef reservoirs on the example of the Pushkinskoye field]. Sbornik nauchnykh statei I konferentsii molodykh uchenykh $i$ spetsialistov OOO "LUKOIL-Inzhiniring". Moscow, 2011, pp. 29-34.

11. Putilov I.S., Kozlova I.A., Fil'kina N.A. Ispol'zovanie metodov litologo-fatsial'nogo analiza dlia utochneniia geologicheskogo stroeniia karbonatnykh zalezhei mestorozhdenii Solikamskoi depressii [Using of methods of lithologic-facial analysis to specify geological structure of carbonate deposits of Solikamsk depression]. Neftepromyslovoe delo, 2010, no. 7, pp. 32-36.

12. Putilov I.S. Razrabotka tekhnologii kompleksnogo izucheniia geologicheskogo stroeniia $i$ razmeshcheniia mestorozhdenii nefti i gaza [Development of technologies for a comprehensive study of the geological structure and placement of oil and gas fields]. Perm': Permskii natsional'nyi issledovatel'skii politekhnicheskii universitet, 2014, 285 p.

13. Raznitsyn A.V. Litologo-fatsial'nyi analiz nizhnefamenskikh otlozhenii Magovskogo mestorozhdeniia [Lithological-facies analysis of the Lower Famennian deposits of the Magovskoye field]. Problemy razrabotki mestorozhdenii uglevodorodnykh i rudnykh poleznykh iskopaemykh, 2016, no. 1, pp. 28-31.

14. Gabnasyrov A.V., Popova N.S., Nekrasov A.S. Izuchenie slozhno prostroennykh kollektorov famensko-turneiskikh otlozhenii Magovskogo mestorozhdeniia po dannym GIS [Studying of complicatedly-composed collectors of FamennianTournaisian deposits of Magovsky oil field on the basis of the data, obtained during well geophysical survey]. Geologiia, geofizika $i$ razrabotka neftianykh i gazovykh mestorozhdenii, 2012, no. 4, pp. 82-85.

15. Surina V.V. Karbonatnye porody famenskogo iarusa Magovskogo mestorozhdeniia Permskogo kraia [Carbonate rocks of the Famen reference of the Magovsky field of the Perm region]. Geologiia v razvivaiushchemsia mire. Sbornik nauchnykh trudov po materialam XII Mezhdunarodnoi nauchno-prakticheskoi konferentsii studentov, aspirantov $i$ molodykh uchenykh. Ed. Iu.A. Bashurova. Perm', 2019, pp. 61-62.

16. Tomilina E.M. Rezul'taty issledovaniia veshchestvennogo sostava karbonatnykh porod Magovskogo mestorozhdeniia [Results of the study of the material composition of the carbonate rocks of the Magovskoye field]. Geologiia $i$ poleznye iskopaemye Zapadnogo Urala, 2015, no. 15, pp. 60-62.

17. Systerova Ia.A. Litologo-Fatsial'nyi analiz verkhnefamenskikh otlozhenii Magovskogo mestorozhdeniia [Lithological-facies analysis of the Upper Famennian deposits of the Magovskoye field]. Problemy razrabotki mestorozhdenii uglevodorodnykh i rudnykh poleznykh iskopaemykh, 2016, no 1 , pp. 44-47. 
18. Martiushev D.A. Razrabotka metodiki opredeleniia koeffitsienta produktivnosti karbonatnykh kollektorov Solikamskoi depressii [Development of the method of determining the coefficient of productivity of carbonate reservoirs Solikamsk depression]. Burenie i neft', 2016, no. 2, pp. 26-29.

19. Raznitsyn A.V. Osobennosti fatsial'nogo stroeniia Magovskogo mestorozhdeniia [Features of the facies structure of the Magovskoye field]. Problemy razrabotki mestorozhdenii uglevodorodnykh $i$ rudnykh poleznykh iskopaemykh, 2017, no. 1 , pp. 51-55.

20. Karmanov A.Iu. Otsenka effektivnosti bureniia novykh skvazhin turneisko-famenskogo ob"ekta Magovskogo mestorozhdeniia [Evaluation of drilling new wells TournaisianFamennian Magovskogo deposit facility]. Vestnik Permskogo natsional'nogo issledovatel'skogo politekhnicheskogo universiteta. Geologiia. Neftegazovoe i gornoe delo, 2012, no. 3, pp. 73-87.

21. Nugaibekov R.A., Shafigullin R.I., Kaptelinin O.V. Otsenka effektivnosti sistemy zavodneniia na zalezhakh nefti $\mathrm{v}$ karbonatnykh kollektorakh Novo-Elkhovskogo mestorozhdeniia [Evaluation of the efficiency of a waterflooding system on oil deposits in carbonate reservoirs of the Novo-Elkhovskoye field]. Ekspluatatsiia neftianykh i gazovykh mestorozhdenii i podgotovka nefti, 2011, no. 3 (85), pp. 5-12.

22. Andreev V.E., Chudinova D.Iu., Chizhov A.P., Chibisov A.V. Optimizatsiia sistemy zavodneniia v terrigennykh i karbonatnykh kollektorakh [Optimization of waterflooding system in terrigenous and carbonate reservoirs]. Problemy sbora, podgotovki i transporta nefti i nefteproduktov, 2016, no. 4 (106), pp. 42-53.

23. Arslanova L.Z., Malyshev P.M., Khalikov R.V. Geologofizicheskie osobennosti primeneniia technologii tsiklicheskogo zavodneniia karbonatnykh kollektorov na pozdnei stadii ikh ekspluatatsii [Geological and physical aspects of cyclic waterflood applications in carbonate reservoirs at late states of their development]. Neftianaia provintsiia, 2016, no. 2, pp. 19-32. DOI: 10.25689/NP.2016.2.19-32

24. Akhmetgareev V.V., Bakirov A.I. Analiz effektivnosti i optimizatsiia parametrov zavodneniia pri razrabotke karbonatnykh kollektorov mestorozhdenii Tatarstana [Analysis and optimization of waterflooding performance in carbonate reservoirs of the republic of Tatarstan]. Neftianoe khoziaistvo, 2013, no. 7, pp. 28-29.

25. Bakirov I.I., Bakirov A.I., Bakirov I.M. Izuchenie effektivnosti razrabotki zavodneniem karbonatnykh otlozhenii [Studying the efficiency of waterflood development of carbonate deposits]. Neftianaia provintsiia, 2019, no. 4 (20), pp. 172-182. DOI: $10.25689 /$ NP.2019.4.172-183

26. Bravicheva T.B., Maslennikova L.V. Povyshenie effektivnosti vyrabotki karbonatnykh kollektorov pri zavodnenii [Increase of the productivity efficiency of carbonate collectors while flooding]. Burenie i neft', 2007, no. 9, pp. 26-27.

27. Galkin V.I., Ponomareva I.N., Repina V.A. Issledovanie protsessa nefteizvlecheniia $\mathrm{v}$ kollektorakh razlichnogo tipa pustotnosti $\mathrm{s}$ ispol'zovaniem mnogomernogo statisticheskogo analiza [Study of oil recovery from reservoirs of different void types with use of multidimensional statistical analysis]. Vestnik Permskogo natsional'nogo issledovatel'skogo politekhnicheskogo universiteta. Geologiia. Neftegazovoe $i$ gornoe delo, 2016, vol. 15, no. 19, pp. 145-154. DOI: $10.15593 / 2224-9923 / 2016.19 .5$

28. Grishin P.A., Kovalev P.M, Fomkin A.V. Perspektivy primeneniia ionno-modifitsirovannoi vody dlia zavodneniia karbonatnykh kollektorov [Prospects of the ion modified water application for the carbonate reservoirs flooding]. Neftianoe khoziaistvo, 2015, no. 10, pp. 98-102.

29. Zeigman Iu.V., Mukhametshin V.V. Obosnovanie sootvetstviia sistem zavodneniia osobennostiam geologicheskogo stroeniia zalezhei [Justification of the compliance of waterflooding systems with the peculiarities of the geological structure of deposits]. Neftepromyslovoe delo, 2009, no. 5, pp. 10-12.

30. Cherepanov S.S., Martiushev D.A., Ponomareva I.N. Otsenka fil'tratsionno-emkostnykh svoistv treshchinovatykh karbonatnykh kollektorov mestorozhdenii predural'skogo kraevogo progiba [Evaluation of filtration-capacitive properties of fractured carbonate reservoir of predural'skogo edge deflection]. Neftianoe khoziaistvo, 2013, no. 3, pp. 62-65.

31. Melekhin S.V., Mikhailov N.N. Eksperimental'noe issledovanie mobilizatsii ostatochnoi nefti pri zavodnenii karbonatnykh kollektorov [Experimental study of the residual oil mobilization at carbonate reservoirs flooding]. Neftianoe khoziaistvo, 2015, no. 8, pp. 72-76.

32. Mikhailov N.N., Bondarenko A.V., Kovalevskii A.I., Li Kai. Vliianie struktury porovogo prostranstva porod-kollektorov na effektivnost' realizatsii tekhnologii polimernogo zavodneniia [Influence of the structure of rock-collectors porous space on the efficiency of polymer water-flooding technology implementation]. Geologiia, geofizika i razrabotka neftianykh $i$ gazovykh mestorozhdenii, 2019, no. 4 (328), pp. 35-40. DOI: 10.30713/2413-5011-2019-4(328)-35-40

33. Shustef I.N. Raschet protsessa obvodneniia v porovotreshchinnom plaste pri razlichnom davlenii nagnetaniia [Calculation flooding process in porous-fractured formation at various discharge pressure]. Neftianoe khoziaistvo, 1976, no. 9, pp. 41-43.

34. Vinnikovskii S.A., Viktorin V.D., Shustef I.N. Effektivnost' sistemy zavodneniia, primeniaemykh na mestorozhdeniiakh Permskoi oblasti [The efficiency of the waterflooding system used in the fields of the Perm region]. Neftianoe khoziaistvo, 1972, no. 9, pp. 31-35.

35. Mordvinov V.A., Martiushev D.A., Ladeishchikova T.S., Golanov N.P. Otsenka vliianiia estestvennoi treshchinovatosti kollektora na dinamiku produktivnosti dobyvaiushchikh skvazhin Ozernogo mestorozhdeniia [Estimation of effects of natural reservoir fracturing on producing well performance]. Vestnik Permskogo natsional'nogo issledovatel'skogo politekhnicheskogo universiteta. Geologiia. Neftegazovoe i gornoe delo, 2015, no. 14, pp. 32-37. DOI: $10.15593 / 2224-9923 / 2015.14 .4$

36. Kadyrov R.R., Nizaev R.Kh., Iartiev A.F., Mukhametshin V.V. Ogranichenie vodopritoka $\mathrm{v}$ gorizontal'nykh skvazhinakh na mestorozhdeniiakh s trudnoizvlekaemymi zapasami nefti [A novel water shut-off technique for horizontal wells at fields with hardto-recover oil reserves]. Neftianoe khoziaistvo, 2017, no. 5, pp. 44-47. DOI: 10.24887/0028-2448-2017-5-44-47

37. Alvarado V., Manrik E. Metody uvelicheniia nefteotdachi pastov. Planirovanie i strategii primeneniia [Methods for enhancing oil recovery of pastes. Planning and application strategies]. Promyshlennyi inzhiniring, 2011, no. 1031.

38. Surguchev M.L. Vtorichnye i tretichnye metody uvelicheniia nefteotdachi plastov [Secondary and tertiary methods of enhanced oil recovery]. Moscow: Nedra, 1985.

39. Fomkina A.V., Zhdanova S.A. Tekhnologiia povysheniia nefteotdachi razrabatyvemykh mestorozhdenii [Enhanced oil recovery technology for developed fields]. Moscow: Vserossiiskii neftegazovyi nauchno-issledovatel'skii institut, 2014, $142 \mathrm{p}$.

40. Taipova V.A., Shaidullin A.A., Shamsutdinov M.F. Gorizontal'nye skvazhiny i gidrorazryv $\mathrm{v}$ povyshenii effektivnosti razrabotki neftianykh mestorozhdenii na primere NGDU "AZNAKAUVSKNEFT" PAO "TATNEFT" [Role Of Horizontal Wells and Hydraulic Fracturing in Increasing the Efficiency of Oilfield Development using the Example of Oil and Gas Production Department «Aznakayevskneft» Tatneft PJSC]. Georesursy, 2017, vol. 19, no. 3, pp. 198-203. DOI: https://doi.org/10.18599/grs.19.3.8

41. Minebaev T.R., Minebaev R.R., Kalmykov A.V., Nikiforov G.A. Gidrodinamicheskoe izuchenie i modelirovanie vliianiia reorganizatsii sistemy zavodneniia na razrabotku zalezhei nefti $\mathrm{v}$ turneiskikh otlozheniiakh Onbiiskogo mestorozhdeniia [Hydrodynamic studies and simulation of the impact of 
waterflooding pattern restructuring on oil pools development in Tournaisian formations of Onbijsky field]. Nauka o zemle, 2019, no. 2, pp. 38-47.

42. Martiushev D.A. Laboratornye issledovaniia kislotnykh sostavov dlia obrabotki kollektorov, kharakterizuiushchikhsia razlichnoi karbonatnost'iu i strukturoi pustotnogo prostranstva gornykh porod [Laboratory studies of acid compositions for treating reservoir, characterized by various carbonate content and void structure of rocks]. Izvestiia Tomskogo politekhnicheskogo universieta. Inzhiniring georesursov, 2018, vol. 329 , no. 4 , pp. 6-12.

43. Voevodkin V.L., Raspopov A.V., Muzhikova L.N., Kondrat'ev S.A. Primenenie novykh tekhnologicheskikh reshenii v oblasti razrabotki na mestoozhdeniiakh OOO "LUKOIL-PERM"" [Application of new technological solutions in the field of oil \& gas development in the oilfields of LUKOIL-PERM LLC]. Neftianoe khoziaistvo, 2012, no. 12, pp. 104-106.

44. Wenchao Liu, Qitao Zhang, Weiyao Zhu Numerical simulation of multi-stage fractured horizontal well in lowpermeable oil reservoir with threshold pressure gradient with moving boundary. Journal of Petroleum Science and Engineering, 2019, vol. 178, pp. 1112-1127. DOI: $10.1016 /$ j.petrol.2019.04.033

45. Ren Long, Su Yuliang, Zhan Shiyuan, Meng Fankun, Zhao Guangyuan Fully coupled fluid-solid numerical simulation of stimulated reservoir volume (SRV)-fractured horizontal well with multi-porosity media in tight oil reservoirs. Journal of Petroleum Science and Engineering, 2019, vol. 174, pp. 757-775. DOI: $10.1016 /$ j.petrol.2018.11.080

\section{Библиографический список}

1. Юшков И.Р., Хижняк Г.П., Илюшин П.Ю. Разработка и эксплуатация нефтяных и газовых месторождений. - Пермь: Изд-во Перм. нац. исслед. политехн. ун-та, 2013. - 177 с.

2. Распопов А.В., Казанцев А.С., Антонов Д.В. Влияние мониторинга разработки на повышение эффективности эксплуатации нефтяных месторождений Пермского края // Нефтяное хозяйство. - 2012. - № 6. - С. 58-61.

3. Воеводкин В.Л., Чертенков М.В. Новые технологии в компании «ЛУКОЙЛ»: от простого к сложному // Нефтяное хозяйство. - 2019. - № 8. - С. 62-66. DOI: $10.24887 / 0028-2448-2019-8-62-66$

4. Зайцев Р.А., Мартюшев Д.А. Эксплуатация скважин с горизонтальным окончанием в различных геолого-физических условиях (на примере месторождений Пермского края) // Бурение и нефть. - 2019. - № 5. - С. 42-46.

5. Мартюшев Д.А. Подход к определению производительности скважин в трещинно-поровых коллекторах Верхнего Прикамья // Бурение и нефть. - 2015. № 2. - С. 44-46.

6. Мартюшев Д.А., Илюшин П.Ю. Экспресс-оценка взаимодействия между добывающими и нагнетательными скважинами на турне-фаменской залежи Озерного месторождения // Вестник Пермского национального исследовательского политехнического университета. Геология. Нефтегазовое и горное дело. - 2016. - Т. 15, № 18. C. 33-41. DOI: 10.15593/2224-9923/2016.18.4

7. Мартюшев Д.А., Мордвинов В.А. Изменение дебита скважин нефтегазоконденсатного месторождения при снижении пластовых и забойных давлений // Нефтяное хозяйство. - 2014. - № 1. - С. 67-69.

8. Оценка параметров пласта и продуктивности скважин при его разработке на естественном режиме / В.А. Мордвинов, Д.А. Мартюшев, И.А. Черных, В.И. Пузиков // Нефтяное хозяйство. - 2014. - № 6. - С. 31-33.

9. Путилов И.С. Применение вероятностностатистического анализа для изучения фациальной зональности турней-фаменского карбонатного комплекса
Соликамской депрессии // Геология, геофизика и разработка нефтяных и газовых месторождений. - 2007. № 10. - С. 16-19.

10. Путилов И.С., Винокурова Е.Е., Бояршинова М.Г. Применение методики изучения литолого-фациального строения рифовых резервуаров на примере Пушкинского месторождения // Сб. науч. ст. I конференции молодых ученых и специалистов ООО «ЛУКОЙЛ-Инжиниринг». M., 2011. - C. 29-34.

11. Путилов И.С., Козлова И.А., Филькина Н.А. Использование методов литолого-фациального анализа для уточнения геологического строения карбонатных залежей месторождений Соликамской депрессии // Нефтепромысловое дело. - 2010. - № 7. - С. 32-36.

12. Путилов И.С. Разработка технологий комплексного изучения геологического строения и размещения месторождений нефти и газа: монография. - Пермь: Изд-во Перм. нац. исслед. политехн. ун-та, 2014. - 285 с.

13. Разницын А.В. Литолого-фациальный анализ нижнефаменских отложений Маговского месторождения // Проблемы разработки месторождений углеводородных и рудных полезных ископаемых. - 2016. - № 1. - С. 28-31.

14. Габнасыров А.В., Попова Н.С., Некрасов А.С. Изучение сложно простроенных коллекторов фаменско-турнейских отложений Маговского месторождения по данным ГИС // Геология, геофизика и разработка нефтяных и газовых месторождений. - 2012. - № 4. - С. 82-85.

15. Сурина В.В. Карбонатные породы фаменского яруса Маговского месторождения Пермского края // Геология в развивающемся мире: сборник науч. тр. по материалам XII Междунар. науч.-практ. конф. студентов, аспирантов и молодых ученых / отв. ред. Ю.А. Башурова. - Пермь, 2019. - С. 61-62.

16. Томилина Е.М. Результаты исследования вещественного состава карбонатных пород Маговского месторождения // Геология и полезные ископаемые Западного Урала. 2015. - № 15. - С. 60-62.

17. Сыстерова Я.А. Литолого-фациальный анализ верхнефаменских отложений Маговского месторождения // Проблемы разработки месторождений углеводородных и рудных полезных ископаемых. - 2016. - № 1. - С. 44-47.

18. Мартюшев Д.А. Разработка методики определения коэффициента продуктивности карбонатных коллекторов Соликамской депрессии // Бурение и нефть. - 2016. - № 2. C. $26-29$.

19. Разницын А.В. Особенности фациального строения Маговского месторождения // Проблемы разработки месторождений углеводородных и рудных полезных ископаемых. - 2017. - № 1. - С. 51-55.

20. Карманов А.Ю. Оценка эффективности бурения новых скважин турнейско-фаменского объекта Маговского месторождения // Вестник Пермского национального исследовательского политехнического университета. Геология. Нефтегазовое и горное дело. - 2012. - № 3. - С. 73-87.

21. Нугайбеков Р.А., Шафигуллин Р.И., Каптелинин О.В. Оценка эффективности системы заводнения на залежах нефти в карбонатных коллекторах Ново-Елховского месторождения // Эксплуатация нефтяных и газовых месторождений и подготовка нефти. - 2011. - № 3 (85). - С. 5-12.

22. Оптимизация системы заводнения в терригенных и карбонатных коллекторах / В.Е. Андреев, Д.Ю. Чудинова, А.П. Чижов, А.В. Чибисов // Проблемы сбора, подготовки и транспорта нефти и нефтепродуктов. - 2016. - № 4 (106). C. $42-53$.

23. Арсланова Л.3., Малышев П.М., Халиков Р.В. Геолого-физические особенности применения технологии циклического заводнения карбонатных коллекторов на поздней стадии их эксплуатации // Нефтяная провинция. 2016. - № 2. - C. 19-32. DOI: 10.25689/NP.2016.2.19-32 
24. Ахметгареев В.В., Бакиров А.И. Анализ эффективности и оптимизация параметров заводнения при разработке карбонатных коллекторов месторождений Татарстана // Нефтяное хозяйство. - 2013. - № 7. - С. 28-29.

25. Бакиров И.И., Бакиров А.И., Бакиров И.М. Изучение эффективности разработки заводнением карбонатных отложений // Нефтяная провинция. - 2019. - № 4 (20). C. $172-182$. DOI: $10.25689 / \mathrm{NP} .2019 .4 .172-183$

26. Бравичева Т.Б., Масленникова Л.В. Повышение эффективности выработки карбонатных коллекторов при заводнении // Бурение и нефть. - 2007. - № 9. - С. 26-27.

27. Галкин В.И., Пономарева И.Н., Репина В.А. Исследование процесса нефтеизвлечения в коллекторах различного типа пустотности с использованием многомерного статистического анализа // Вестник Пермского национального исследовательского политехнического университета. Геология. Нефтегазовое и горное дело. - 2016. - Т. 15, № 19. - С. 145-154. DOI: $10.15593 / 2224-9923 / 2016.19 .5$

28. Гришин П.А., Ковалев П.М, Фомкин А.В. Перспективы применения ионно-модифицированной воды для заводнения карбонатных коллекторов // Нефтяное хозяйство. - 2015. № 10. - С. 98-102.

29. Зейгман Ю.В., Мухаметшин В.В. Обоснование соответствия систем заводнения особенностям геологического строения залежей // Нефтепромысловое дело. - 2009. - № 5. - С. 10-12.

30. Черепанов С.С., Мартюшев Д.А., Пономарева И.Н. Оценка фильтрационно-емкостных свойств трещиноватых карбонатных коллекторов месторождений предуральского краевого прогиба // Нефтяное хозяйство. - 2013. - № 3. - С. 62-65.

31. Мелехин С.В., Михайлов Н.Н. Экспериментальное исследование мобилизации остаточной нефти при заводнении карбонатных коллекторов // Нефтяное хозяйство. - 2015. № 8. - С. 72-76.

32. Влияние структуры порового пространства породколлекторов на эффективность реализации технологии полимерного заводнения / Н.Н. Михайлов, А.В. Бондаренко, А.И. Ковалевский, Кай Ли // Геология, геофизика и разработка нефтяных и газовых месторождений. - 2019. - № 4 (328). C. 35-40. DOI: 10.30713/2413-5011-2019-4(328)-35-40

33. Шустеф И.Н. Расчет процесса обводнения в поровотрещинном пласте при различном давлении нагнетания // Нефтяное хозяйство. - 1976. - № 9. - С. 41-43.

34. Винниковский С.А., Викторин В.Д., Шустеф И.Н. Эффективность системы заводнения, применяемых на месторождениях Пермской области // Нефтяное хозяйство. 1972. - № 9. - С. 31-35.

35. Оценка влияния естественной трещиноватости коллектора на динамику продуктивности добывающих скважин Озерного месторождения / В.А. Мордвинов, Д.А. Мартюшев, Т.С. Ладейщикова, Н.П. Голанов // Вестник Пермского национального исследовательского политехнического университета. Геология. Нефтегазовое и горное дело. - 2015 . № 14. - С. 32-37. DOI: $10.15593 / 2224-9923 / 2015.14 .4$

36. Ограничение водопритока в горизонтальных скважинах на месторождениях с трудноизвлекаемыми запасами нефти / Р.Р. Кадыров, Р.Х. Низаев, А.Ф. Яртиев, В.В. Мухаметшин // Нефтяное хозяйство. - 2017. - № 5. C. 44-47. DOI: 10.24887/0028-2448-2017-5-44-47

37. Алварадо В., Манрик Э. Методы увеличения нефтеотдачи пастов. Планирование и стратегии применения // Промышленный инжиниринг. - 2011. - № 1031.

38. Сургучев М.Л. Вторичные и третичные методы увеличения нефтеотдачи пластов. - М.: Недра, 1985.

39. Фомкина А.В., Жданова С.А. Технология повышения нефтеотдачи разрабатывемых месторождений. - М.: Изд-во Всерос. нефтегаз. науч.-исслед. ин-та, 2014. - С. 142.

40. Таипова В.А., Шайдуллин А.А., Шамсутдинов М.Ф. Горизонтальные скважины и гидроразрыв в повышении эффективности разработки нефтяных месторождений на Примере НГДУ «АЗНАКАУВСКНЕФТЬ» ПАО «ТАТНЕФТЬ» // Георесурсы. - 2017. - Т. 19, № 3. - С. 198-203. DOI: https://doi.org/10.18599/grs.19.3.8

41. Гидродинамическое изучение и моделирование влияния реорганизации системы заводнения на разработку залежей нефти в турнейских отложениях Онбийского месторождения / Т.Р. Минебаев, Р.Р. Минебаев, А.В. Калмыков, Г.А. Никифоров // Наука о земле. - 2019. № 2. - C. 38-47.

42. Мартюшев Д.А. Лабораторные исследования кислотных составов для обработки коллекторов, характеризующихся различной карбонатностью и структурой пустотного пространства горных пород // Известия Томского политехнического университета. Инжиниринг георесурсов. 2018. - Т. 329, № 4. - C. 6-12.

43. Применение новых технологических решений в области разработки на месторождениях ООО «ЛУКОЙЛПЕРМЬ» / В.Л. Воеводкин, А.В. Распопов, Л.Н. Мужикова, С.А. Кондратьев // Нефтяное хозяйство. - 2012. - № 12. C. $104-106$.

44. Wenchao Liu, Qitao Zhang, Weiyao Zhu Numerical simulation of multi-stage fractured horizontal well in lowpermeable oil reservoir with threshold pressure gradient with moving boundary // Journal of Petroleum Science and Engineering. - 2019. - Vol. 178. - P. 1112-1127. DOI: $10.1016 /$ j.petrol.2019.04.033

45. Fully coupled fluid-solid numerical simulation of stimulated reservoir volume (SRV)-fractured horizontal well with multi-porosity media in tight oil reservoirs / Long Ren, Yuliang Su, Shiyuan Zhan, Fankun Meng, Guangyuan Zhao // Journal of Petroleum Science and Engineering. - 2019. - Vol. 174. P. 757-775. DOI: 10.1016/j.petrol.2018.11.080

Please cite this article in English as:

Lyadova N.A., Demchenko V.A. Waterflooding Efficiency Evaluation on Tournasian-Famennian Deposit of Magovskoye Field. Perm Journal of Petroleum and Mining Engineering, 2020, vol.20, no.3, pp.242-252. DOI: 10.15593/2712-8008/2020.3.5

Просьба ссылаться на эту статью в русскоязычных источниках следующим образом:

Лядова Н.А., Демченко В.А. Оценка эффективности системы заводнения турнейско-фаменской залежи Маговского месторождения // Недропользование. - 2020. - T.20, №3. - C.242-252. DOI: 10.15593/2712-8008/2020.3.5 